\title{
The Use of Solvent/Detergent Treatment in Pathogen Reduction of Plasma
}

\author{
Peter Hellstern $^{a} \quad$ Bjarte G. Solheim ${ }^{b}$ \\ a Institute of Hemostaseology and Transfusion Medicine, Academic City Hospital Ludwigshafen, Ludwigshafen, Germany

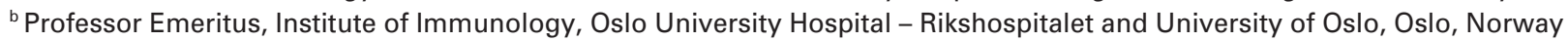

\author{
Key Words \\ Solvent/detergent-treated plasma $\cdot$ Pathogen inactivation . \\ Transfusion-associated acute lung injury . \\ Allergic reactions - Clinical efficacy . \\ Tolerance
}

\section{Summary}

The solvent/detergent (SD) process used for plasma can safely inactivate all lipid-enveloped viruses. The introduction of a specific prion-binding ligand gel in combination with SD treatment, time-reduced from 4 to $1-1.5 \mathrm{~h}$, still ensures efficient virus kill, reduces abnormal prion protein by $>5$ log steps, and preserves levels of plasmin inhibitor at close to the reference range. Infections with known nonenveloped viruses such as HAV or parvovirus B19 are prevented by ensuring low virus loads in the starting plasma units, dilution through pooling of single plasma units, and neutralization of immune antibodies already present in the initial plasma pools. The major advantages of SD plasma over fresh frozen plasma and the other pathogen-inactivated plasmas are its extreme safety with respect to transfusion-related acute lung injury and the significantly lower likelihood of provoking allergic reactions. Both advantages are best interpreted as results of the dilution effect of pooling. No fewer than 18 clinical studies covering all indications for plasma, and extensive clinical experience have shown that reduced levels of coagulation factors and inhibitors as a result of SD treatment do not impair significantly the clinical efficacy or tolerance of plasma. Properly standardized clotting factor and inhibitor potencies and low batch-to-batch variations when compared with single-donor plasma units makes SD plasma more suitable for standardized treatment.

\author{
Schlüsselwörter \\ Solvent/Detergens-behandeltes Plasma . \\ Pathogeninaktivierung - Transfusionsassoziierte akute \\ Lungeninsuffizienz - Allergische Reaktionen . \\ Klinische Wirksamkeit · Verträglichkeit
}

\section{Zusammenfassung}

Das für Plasma angewandte Solvent/Detergens(SD)-Verfahren inaktiviert alle lipidumhüllten Viren sicher. Die mit dem Einsatz eines spezifischen Prionen bindenden Ligandengels eingeführte Reduktion der Inkubationszeit mit SD von 4 auf $1-1,5 \mathrm{~h}$ stellt weiterhin eine vollständige Inaktivierung aller lipidumhüllten Viren sicher, reduziert abnormes Prionenprotein um über 5 Log-Stufen und resultiert in Plasmininhibitor-Aktivitäten, die nur geringfügig unterhalb des Referenzbereichs liegen. Infektionen mit nichtlipidumhüllten Viren wie HAV und Parvovirus B19 werden durch Sicherstellung niedriger Virusbelastungen im Ausgangsmaterial, Verdünnung durch das Poolen von Einzelspenderplasmen und durch im Plasmapool enthaltene neutralisierende Antikörper verhindert. Die wesentlichen Vorteile von SD-Plasma gegenüber gefrorenem Frischplasma (GFP) und anderen pathogeninaktivierten Einzelspenderplasmen bestehen in seiner hohen Sicherheit in Bezug auf das Risiko für die transfusionsassoziierte akute Lungeninsuffizienz und in deutlich weniger allergischen Reaktionen. Beide Vorteile dürften hauptsächlich auf die Verdünnung durch das Poolen zurückzuführen sein. Mindestens 18 klinische Studien, die alle Indikationen für Plasma umfassten, und umfassende klinische Erfahrung haben gezeigt, dass die im SD-Plasma gegenüber GFP etwas reduzierten Konzentrationen der Gerinnungsfaktoren und Inhibitoren zu keiner signifikanten Minderung der klinischen Wirksamkeit und Verträglichkeit führen. Die im SD-Plasma gut standardisierten Aktivitäten der Gerinnungsfaktoren und Inhibitoren und niedrige Schwankungen von Charge zu Charge erlauben eine besser standardisierte Therapie mit SD-Plasma als mit Einzelspenderpräparaten.

\begin{tabular}{ll}
\hline KARGER & ( ) 2011 S. Karger GmbH, Freiburg \\
Fax +497614520714 & Accessible online at: \\
Information@Karger.de & www.karger.com/tmh \\
www.karger.com &
\end{tabular}

Prof. Dr. med. Peter Hellstern

Institut für Hämostaseologie und Transfusionsmedizin

Klinikum Ludwigshafen

Bremserstraße 79, 67063 Ludwigshafen, Germany

peterhellstern@medicusnet.de 


\section{Introduction}

The solvent/detergent (SD) method to inactivate enveloped viruses in plasma protein preparations was first developed in the early 1980s [1]. The method proved effective in the processing of coagulation factor concentrates by disrupting the membranes of lipid-enveloped viruses, cells and most protozoa, while leaving the labile coagulation factors intact. Its efficacy with respect to bacteria is more variable generally, and it is ineffective against non-lipid-enveloped viruses. The SD process is the most widely used and best validated and robust pathogen inactivation technology known today [2], and many million doses of SD-treated plasma proteins have been transfused without any report of transmission of enveloped viruses.

\section{Solvent/Detergent Treatment of Plasma - Research, Development and Manufacture}

Unlike coagulation factor concentrates, the composition of plasma is very complex. Because the effect of plasma in transfusion medicine depends heavily on proteins that seemed resistant to SD treatment, Bernhard Horowitz proposed in 1986/1987 the development of a method to treat plasma with SD. Unable to arouse interest or find financing in the USA, he turned to Octapharma (Octapharma AG, Lachen, Switzerland), that agreed to finance the laboratory effort at the New York Blood Center (NYBC) in exchange for European marketing rights. Laboratory work was complete by 1989, 1 year after its initiation, and the experimental process was handed off to Octapharma [3]. Working with the German Red Cross Center in Hagen, Germany, Octapharma matured the laboratory process to a form suitable for industrial-scale manufacturing. Characterization of the manufactured product was published in 1992 [4], at which time also Horowitz and his collaborators published their results [5]. Biesert and Shartono [6] subsequently validated the robustness of SD plasma treatment in their study of the virus safety of Octaplas ${ }^{\circledR}$ (Octapharma AG, Lachen, Switzerland).

\section{The Chemistry of SD Treatment of Plasma}

The concentration of tri-(N-butyl)-phosphate (TNBP) was increased from 0.3 to $1 \%$ to accommodate the lipid content of plasma, and temperature was raised to $30{ }^{\circ} \mathrm{C}$ for $4 \mathrm{~h}$ to ensure efficient virus kill $[4,5]$. Sodium cholate, the usual detergent used in the SD treatment of coagulation factors, was substituted by $1 \%$ polyoxyethylene-p-t-octylphenol (Triton X-100), because it can easily be removed together with TNBP by a simple and effective hydrophobic chromatographic step [7]. TNBP acts as an organic solvent to remove lipids from the membranes of pathogens and is used alone in some protocols. Triton X-100 is a non-ionic detergent that stabilizes TNBP and disrupts lipid bilayers, thus easing the extraction of lipids [8]. In some processes, a final step involves adding soybean or castor oil to the
SD plasma mixture to remove solvent and detergent [3, 9]. SD treatment is preceded by filtration with a $1 \mu \mathrm{m}$ filter to remove cells and debris, followed by sterile filtration into bags or vials using a $0.2 \mu \mathrm{m}$ filter and aseptic filling [9]. Once manufacture of SD plasma at the Red Cross Center in Hagen was underway, Octapharma introduced the process to its factory in Vienna and licensed the process to the French Transfusion Service, which began the manufacture of SD plasma at the Centre régional de transfusion sanguine (CRTS) in Bordeaux in 1992 $[11,12]$. In the latter half of the 1990s, the National Bioproducts Institute (NBI) of Pinetown, South Africa, developed ABO-independent, universal plasma (Bioplasma FDP ${ }^{\circledR}$ ) using the SD treatment manufacturing process licensed from Octapharma [13]. A universal SD plasma developed by Octapharma (working title Uniplas) is now in the final stages of licensing. Kedrion (Castelvecchio Pascoli, Italy) introduced SD plasma (Plasmasafe $^{\circledR}$ ) in 2005, also using Octapharma's licensed manufacturing process. Production of SD plasma at the German Red Cross Center in Hagen ended in 2006.

In the USA the Federal Drug Administration's (FDA) attitude toward SD plasma became gradually more positive, and in 1991-1992 manufacturing of SD plasma using many of the same procedures pioneered in Europe by Octapharma began, initially at Melville Biologics (a division of NYBC); later, due to lack of adequate resources at NYBC, manufacturing was transferred to a spin-off, V.I Technologies, Inc. (VITEX) [3, 14]. VITEX (Watertown, MA, USA) subsequently produced the American SD plasma, PLAS $+\mathrm{SD}^{\mathrm{TM}}$.

Except for differences in the plasma pool size, 601 in France, 2001 in Germany and South Africa, 3801 in Austria and up to 6501 in the USA, SD plasma has until recently been manufactured by similar, though not identical methods. Today, Octapharma has launched OctaplasLG ${ }^{\circledR}$, an SD plasma whose manufacture involves an additional chromatographic step combining a specific prion-binding ligand gel with SD treatment, time-reduced from 4 to $1-1.5 \mathrm{~h}$ [15].

For mini-pools of 5-10 1 of plasma, SD treatment may be performed in closed multi-bag systems with only $2 \%$ TNBP, or $1 \%$ TNBP when $1 \%$ Triton $\mathrm{X}-45$ is used instead of $1 \%$ Triton X-100 [16, 17]. The SD treatment is then performed at $31{ }^{\circ} \mathrm{C}$ for $4 \mathrm{~h}$, followed by $2-3$ oil extraction steps optionally followed by hydrophobic chromatography. For pathogen reduction by solvent only ( $2 \%$ TNBP), incubation temperature is increased to $37{ }^{\circ} \mathrm{C}$. This 'mini-pool' system was pioneered by Burnouf in collaboration with Egyptian blood bankers [16] for use under GMP conditions in blood banks of resourcelimited countries.

The features of the different SD plasma products are shown in table 1.

\section{Virus Inactivation}

The SD treatment of plasma results in a prompt and large reduction of enveloped viruses with a high reserve capacity [18]. The inactivation rate for enveloped viruses in plasma is 
Table 1. Features of different SD plasma products

\begin{tabular}{|c|c|c|c|c|c|}
\hline Type of plasma & Source and quality & Pool size & $\begin{array}{l}\text { Inactivation time and } \\
\text { temperature }\end{array}$ & $\begin{array}{l}\text { Removal of abnormal } \\
\text { prion binding protein } \\
\left(\mathrm{PrP}^{\mathrm{Sc}}\right)\end{array}$ & Final product \\
\hline Octaplas (Austria) & $\begin{array}{l}\text { high-quality } \\
\text { apheresis or } \\
\text { recovered plasma* }\end{array}$ & $\begin{array}{l}3801 \\
(630 \text { apheresis units or } \\
1,520 \text { recovered units) }\end{array}$ & $\begin{array}{l}4 \mathrm{~h} \text { at } 30^{\circ} \mathrm{C} \\
(1 \% \mathrm{TNBP}+1 \% \text { Triton } \mathrm{X}-100)\end{array}$ & $\begin{array}{l}2.5 \mathrm{log} \text { reduction of } \\
\mathrm{PrP}^{\mathrm{Sc}} \text { as a result of the } \\
\mathrm{SD} \text { manufacturing } \\
\text { process }\end{array}$ & $\begin{array}{l}200 \mathrm{ml} \text { frozen } \\
\text { in plastic bags }\end{array}$ \\
\hline OctaplasLG (Austria) & $\begin{array}{l}\text { high-quality } \\
\text { apheresis or } \\
\text { recovered plasma* }\end{array}$ & $\begin{array}{l}3801 \\
(630 \text { apheresis units or } \\
1,520 \text { recovered units) }\end{array}$ & $\begin{array}{l}1-1.5 \mathrm{~h} \text { at } 30^{\circ} \mathrm{C} \\
(1 \% \text { TNBP }+1 \% \text { Triton } \mathrm{X}-100)\end{array}$ & $\begin{array}{l}>5 \text { log reduction of } \\
\mathrm{PrP}^{\mathrm{Sc}} \text { after additional } \\
\text { affinity chromatography } \\
\text { with } \mathrm{PrP}^{\mathrm{Sc}} \text { binding ligand }\end{array}$ & $\begin{array}{l}200 \mathrm{ml} \text { frozen } \\
\text { in plastic bags }\end{array}$ \\
\hline Plasmasafe (Italy) & $\begin{array}{l}\text { high-quality } \\
\text { apheresis or } \\
\text { recovered plasma* }\end{array}$ & $\begin{array}{l}3801 \\
(630 \text { apheresis units or } \\
1,520 \text { recovered units) }\end{array}$ & $\begin{array}{l}4 \mathrm{~h} \text { at } 30^{\circ} \mathrm{C} \\
(1 \% \mathrm{TNBP}+1 \% \text { Triton } \mathrm{X}-100)\end{array}$ & $\begin{array}{l}\text { not documented, but } \\
\text { probably similar to } \\
\text { Octaplas }\end{array}$ & $\begin{array}{l}200 \mathrm{ml} \text { frozen } \\
\text { in plastic bags }\end{array}$ \\
\hline $\begin{array}{l}\text { Plasma viro-atténué } \\
\text { Solvant détergent } \\
\text { (France) }\end{array}$ & $\begin{array}{l}\text { high-quality } \\
\text { apheresis plasma }\end{array}$ & $\begin{array}{l}601 \\
\text { (100 apheresis units) }\end{array}$ & $\begin{array}{l}4 \mathrm{~h} \text { at } 30^{\circ} \mathrm{C} \\
(1 \% \mathrm{TNBP}+1 \% \text { Triton } \mathrm{X}-100)\end{array}$ & $\begin{array}{l}\text { not documented, but } \\
\text { probably similar to } \\
\text { Octaplas }\end{array}$ & $\begin{array}{l}200 \mathrm{ml} \text { frozen } \\
\text { in plastic bags }\end{array}$ \\
\hline $\begin{array}{l}\text { Bioplasma FDP } \\
\text { (South Africa) }\end{array}$ & $\begin{array}{l}\text { high-quality } \\
\text { recovered plasma }\end{array}$ & 2001 & $\begin{array}{l}4 \mathrm{~h} \text { at } 30^{\circ} \mathrm{C} \\
(1 \% \mathrm{TNBP}+1 \% \text { Triton } \mathrm{X}-100)\end{array}$ & $\begin{array}{l}\text { not documented, but } \\
\text { probably similar to } \\
\text { Octaplas }\end{array}$ & $\begin{array}{l}50 \text { and } 200 \mathrm{ml} \\
\text { lyophilized in } \\
\text { glass bottles }\end{array}$ \\
\hline PLAS+SD (USA) & $\begin{array}{l}\text { recovered plasma } \\
\text { frozen next day }\end{array}$ & $\begin{array}{l}6501 \\
(2,500 \text { recovered units })\end{array}$ & $\begin{array}{l}4 \mathrm{~h} \text { at } 30^{\circ} \mathrm{C} \\
(1 \% \mathrm{TNBP}+1 \% \text { Triton } \mathrm{X}-100)\end{array}$ & $\begin{array}{l}\text { not documented, but } \\
\text { probably similar to } \\
\text { Octaplas }\end{array}$ & $\begin{array}{l}200 \mathrm{ml} \text { frozen } \\
\text { in plastic bags } \\
\text { (produced } \\
\text { from } 1998 \text { to } \\
2002 \text { ) }\end{array}$ \\
\hline $\begin{array}{l}\text { 'Mini-pool' (for blood } \\
\text { bank application } \\
\text { in resource limited } \\
\text { countries) }\end{array}$ & recovered plasma & $5-101$ & $\begin{array}{l}4 \mathrm{~h} \text { at } 31^{\circ} \mathrm{C} \\
(1 \% \mathrm{TNBP}+1 \% \text { Triton } \mathrm{X}-45) \\
\text { or } \\
4 \mathrm{~h} \text { at } 37^{\circ} \mathrm{C} \\
(2 \% \mathrm{TNBP})\end{array}$ & unknown & $\begin{array}{l}\text { depending } \\
\text { upon local } \\
\text { practice }\end{array}$ \\
\hline
\end{tabular}

extremely high, virus load dropping below detection levels (>6 log steps) in less than $2 \mathrm{~min}[6,14]$, except for vaccinia virus, which inactivation takes $10 \mathrm{~min}$ [12]. So far, all of the tested enveloped viruses, including recently emerging viruses such as West Nile virus, Chikungunya virus, new influenza strains and severe acute respiratory syndrome Coronavirus, are vulnerable to the SD process. Between 1991 and 2009, Octapharma, from its factory in Austria together with licensees in Germany (Red Cross Center, Hagen), France (CRTS, Bordeaux ), Italy (Kedrion) and South Africa (NBI, Pinetown), delivered approximately 10 million units of SD plasma for use in routine medical care. The efficacy of the SD treatment process is underscored by the fact that no documented case of infection with HBV, HCV or HIV as a result of transfusion with SD plasma has been reported. It follows that the original 4-hour incubation time provides an excessive margin of safety, permitting a reduction of incubation time to $1-1.5 \mathrm{~h}$ for OctaplasLG, which has a safety margin still superior to most other pathogen-reducing technologies.
SD treatment has no effect on non-enveloped viruses, but immune antibodies commonly present in plasma provide a measure of protection against infection by the most commonly encountered non-enveloped viruses such as HAV and parvovirus B19 [3, 19, 20]. Upper limits for HAV and parvovirus B19 virus particles in a plasma pool and minimum titers of the corresponding neutralizing antibodies present in plasma pools provide additional safety.

Octapharma and licensees minimize the risk of emerging transfusion-transmitted infections by using pool sizes between 60 and 3801 . This is much smaller than the 4,000-30,000 1 used for plasma protein fractionation and concomitant pathogen reduction.

With regard to prions, the combination of prion ligand gel [21] and the reduction of prions already obtained through the SD treatment process [22] results in $>5$ log reduction of abnormal prion protein (PrPSc) in OctaplasLG. 


\section{Toxicity, Antibodies and Neoantigens}

The European Pharmacopoeia (6.2, July 2008:1646) prescribes residual amounts of SD in plasma no greater than $2 \mu \mathrm{g} / \mathrm{ml}$ of TNBP and $5 \mu \mathrm{g} / \mathrm{ml}$ of Triton X-100. These values are far below the toxicity levels for either substance or ambient environmental exposures in industrialized societies [8]. Actual levels in most SD plasma batches are below the detectable level, which is 0.5 and $1 \mu \mathrm{g} / \mathrm{ml}$, respectively.

Leukocyte antibodies were not detected in pools between 200 and $3801[12,23,24]$ while in the smaller French 601 pools (which are regularly screened) one pool was found positive and discarded [10]. These findings can best be explained by a dilution effect and possible neutralization of leukocyte antibodies by leukocytes and cell fragments present in the original plasma pool, but removed during SD treatment. Dilution may also play a role in the significantly reduced frequency of severe allergic reactions observed following transfusion of SD plasma when compared to methylene blue plasma, psoralen plasma or quarantine plasma [10, 12].

Further substantiation of the safety of the SD treatment is witnessed by the transfusion of about 10 million units of SD plasma, with no report of toxicity or transfusion-associated lung injury (TRALI). Nor have any antibodies against neoantigens been observed or neoantigens reported.

\section{Protein Function in SD Treated Plasma}

Established pathogen reduction procedures involving treatment with methylene blue, psoralen, riboflavin and SD result in the loss of $20-30 \%$ of factor VIII activity and of less than $20 \%$ for most other coagulation factors and inhibitors due to dilution, thawing and freezing [12]. Considering the wide reference range (50-200\%) for most clotting factors and inhibitors in single plasma units, reductions in this order of magnitude do not seem to be clinically significant.

The quality of the fresh frozen plasma (FFP) used for pathogen reduction may also vary widely $[25,26]$. For example, optimal freezing and storage at temperatures below $-20{ }^{\circ} \mathrm{C}$ is important as is the source of plasma and the way in which it is separated. The time interval between collection, separation and freezing is crucial. Apheresis plasma frozen promptly after collection is best followed by recovered plasma frozen within $4 \mathrm{~h}$, which is superior to that frozen within $15 \mathrm{~h}$. Delayed and prolonged freezing reduces all coagulation factor and protease activities while repeated thawing and re-freezing particularly affects coagulation factors V, VIII and XI. Finally, blood group $\mathrm{O}$ and $\mathrm{A} 2$ individuals have significantly lower factor VIII and von Willebrand factor (VWF) plasma levels than subjects with other ABO blood groups.

SD treatment targets lipids and so has little effect on transfusion-relevant proteins in plasma. As a pooled and uniform product with a unit volume of $200 \mathrm{ml}$, SD plasma has low batchto-batch variations in plasma levels of coagulation factors, inhibitors and antibodies, allowing clinicians to predict the plasma transfusion effects more precisely. SD plasma by Octapharma
(Octaplas) and its licensees is produced from optimally separated and frozen plasma, and with a $10-20 \%$ reduction of clotting factor and inhibitor activities has a final composition similar to FFP. Factor VIII activity is about $20 \%$ lower than in FFP. Protein $\mathrm{S}$ activity is reduced by $35 \%$, and plasmin inhibitor activity levels in 200-380 1 pools are only $24-33 \%$ of normal. In the French SD plasma produced from 601 pools, the plasmin inhibitor level is $37-42 \%$ of normal. In 'mini-pool' SD plasma, protein $\mathrm{S}$ and plasmin inhibitor are reduced by only $10-20 \%$ of normal. PLAS+SD, with pool sizes of up to 6501 and less strict quality requirements for the separation and freezing of plasma, had strikingly lower activities of protein S, plasmin inhibitor, plasmin activator inhibitor and antitrypsin than Octaplas [2729]. In the new OctaplasLG, where SD treatment is reduced to $1-1.5 \mathrm{~h}$, the activity of plasmin inhibitor is increased to about $66 \%$ of normal. Thus, incubation time, stress due to pool size and plasma quality all appear to affect plasmin inhibitor. Burnouf et al. [30] has also speculated that Triton X-100 might affect plasmin inhibitor, but, if so, this can be avoided by using the smaller compound Triton X-45. Bleeding problems in liver transplantation with Octaplas produced for Ireland from American plasma may have been due to negative effects caused by delay of freezing, beginning the day after collection [31].

\section{Licensing and Regulations}

In the early 1990s SD plasma was considered a blood product in Germany and France. In most other European countries it was treated as a medicinal product, and the use of SD plasma was often permitted during the registration process because of its obvious virus safety, particularly with regard to HCV. SD plasma was first introduced in 1991 in the German federal state of North Rhine-Westphalia. In Norway, SD plasma replaced FFP in 1993 following a successful clinical trial in 1992 [32]. Currently, ordinary medicinal licensing is required for SD plasma in European countries except France, where it is classed as a labeled blood product. Octaplas is now a licensed biopharmaceutical product in 29 countries worldwide. So far, OctaplasLG has been approved for use in Germany and Australia, and regulatory procedures are ongoing in other European countries. Confirmatory studies on the claimed capacity to remove prions that were requested by some countries are nearing completion. The approval process for Uniplas is also in its final stages (T.E. Svae, Octapharma, personal communication).

In the USA, regulatory approval was long delayed compared to Europe. The FDA's attitude toward SD plasma began to change in 1990-1991. As clinical data accumulated, it became clear that US approval for SD plasma was justified, but the requirement to have sufficient production capacity $(2,000,000$ units/year) and a nation-level distribution partner delayed FDA approval until 1998. By then VITEX had increased its production capacity for SD plasma sufficiently, and the American Red Cross (ARC) was selected as sole distributor. Heated debate ensued, ranging from questions of medical or scientific concern to rising health care costs and the poten- 
Table 2. Properties of different types of therapeutic plasma

\begin{tabular}{|c|c|c|c|c|c|c|}
\hline Therapeutic plasma type & $\begin{array}{l}\text { Pathogen } \\
\text { inactivation }\end{array}$ & $\begin{array}{l}\text { Free of cells and } \\
\text { cell fragments }\end{array}$ & $\begin{array}{l}\text { Risk of TRALI } \\
\text { abolished }\end{array}$ & $\begin{array}{l}\text { Allergic } \\
\text { reactions } \\
\text { reduced }\end{array}$ & $\begin{array}{l}\text { Standardized } \\
\text { coagulation factor } \\
\text { potencies }\end{array}$ & $\begin{array}{l}\text { Full clinical } \\
\text { efficacy in all } \\
\text { settings }\end{array}$ \\
\hline SD plasma & yes & yes & yes & yes & yes & yes \\
\hline MB plasma & yes & no & no & no & no & no* \\
\hline INTERCEPT $^{\mathrm{TM}}$ plasma & yes & no & no & no & no & yes \\
\hline MIRASOL ${ }^{\mathrm{TM}}$ plasma & yes & no & no & no & no & $? * *$ \\
\hline Standard FFP & no & no & no & no & no & yes \\
\hline
\end{tabular}

tial impact on blood center and blood bank revenues and product control. Introduction of PLAS+SD with the ARC logo and the fact that ARC was an exclusive US distributor provoked strong reactions from members of America's Blood Centers, who collect and distribute half of the nation's blood supply. Additionally, the ARC set the price for PLAS+SD $30 \%$ higher than expected. This, along with a number of thromboembolic adverse reactions that had not been observed with European SD plasma resulted in the termination of SD plasma production in the USA in 2002-2003 [3].

\section{Clinical Studies and Experience with SD Plasma}

In general, even high plasma doses result in only moderate increases in coagulation factor and inhibitor plasma levels in the recipient, and several indications for plasma are not based on strong or on any evidence resulting from controlled clinical trials [33].

No fewer than 18 recently reviewed studies and retrospective analyses covering all indications for plasma have been conducted to examine the efficacy and tolerance of SD plasma [10], two of them examining the use of universal SD plasma (Uniplas) in open-heart surgery and in adults undergoing elective liver resection $[34,35]$. Though all of these studies lacked statistical power to detect minor differences due to their small size, they clearly show that the loss of coagulation factor and inhibitor levels caused by SD treatment does not result in any significant loss of clinical efficacy or tolerance. Concerns about the low levels of plasmin inhibitor, protein S, or antitrypsin activity in SD plasma have not been confirmed in clinical studies, and claims of thrombosis or hyperfibrinolytic bleeding triggered by reduced protein $\mathrm{S}$ or low plasmin inhibitor potencies in Octaplas have not withstood critical review [26, 36, 37]. That notwithstanding, the higher level of plasmin inhibitor of OctaplasLG, which approaches the lower normal reference range, is welcome.

Clinical experience with SD plasma has also substantiated the product's safety. Experience from France after transfusion of over 1.9 million units of Plasma viro-atténué Solvant detergent since 1994, from Norway after over 660,000 units of Octaplas since 1993 and from Finland after over 150,000 units of
Octaplas since 2005 demonstrate that all patient groups, including preterm infants and liver transplant patients, can be transfused with SD plasma [11, 38, 39] and that special products such as reconstituted blood can be prepared using SD plasma. Similar experience, except bleeding problems in liver transplantation, have been reported from Ireland where approximately 200,000 units of Octaplas have been transfused after 2002. These bleeding problems could be ascribed to the recovered American plasma used in the production of Octaplas batches for Ireland [31]. So far, more than 700 liver transplants have been performed with good results at Oslo University Hospital, Rikshospitalet, Oslo, with SD plasma as the only plasma component. No cases of thromboembolism have been ascribed to its use. Due to the low content of plasmin inhibitor in Octaplas, aprotinin was initially used frequently in severe liver failure, thus complicating repeat cardiac surgery [40]. Now aprotinin has been successfully substituted with tranexamic acid in cardiac surgery and liver transplantation except in some very few liver transplant patients requiring a broad spectrum serine protease inhibitors [38]. Portugal has also good experience with Octaplas since its introduction in 1995, however, to our knowledge without scientific documentation so far. Hemovigilance data from France, Norway and Finland show significant reductions (approximately 85\%) in serious adverse events. With respect to TRALI no documented events have ever been reported for SD plasma. In the UK more than 350,000 units of Octaplas have been transfused after introduction of the Serious Hazards of Transfusion Hemovigilance system without reports on serious problems. After switching to $100 \%$ SD plasma the annual rate of clinical use has shown very little change in Ireland and Finland [31, 39] while Norway has experienced an increase of about $70 \%$ to 2,0261 per million inhabitants since 1993 [38]. This is still below the mean consumption of 2,386 1 per million inhabitants in Western Europe or 4,153 1 per million in Germany (C.L. van der Poel, Sanquin, The Netherlands, personal communication). The fact that SD plasma is a clear, standardized solution with a defined constant volume and few adverse events has made it particularly popular among anesthesiologists and surgeons. A comparison of the properties of different types of therapeutic plasma is presented in table 2 . 
The major advantage of SD plasma over FFP and the other pathogen inactivation plasmas is its extreme safety with regard to TRALI. Another advantage of SD plasma over FFP is its markedly lower rate of allergic reactions $[10,11,39]$. The advantages of SD plasma with respect to TRALI are best explained by the dilution effect of pooling and, possibly, neutralization of antibodies by residual leukocytes or soluble antigens in the plasma units. The lower number of allergic reactions is likely due to the dilution effect on antibodies and allergens. Not to be discounted is the possibility that SD treatment has a direct or indirect effect on the activated lipids associated with TRALI.

\section{Disclosure Statement}

The authors declared no conflict of interest.

\section{References}

1 Prince AM, Horowitz B, Brotman B: Sterilization of hepatitis and HTLV-III viruses by exposure to tri(n-butyl)phosphate and sodium cholate. Lancet 1986;i:706-710.

2 Dichtelmüller HO, Biesert L, Fabbrizzi F, Gajardo R, Gröner A, von Hoegen I, Jorquera JI, Kempf C, Kreil TR, Pifat D, Osheroff W, Poelsler G: Robustness of solvent/detergent treatment of plasma derivatives: a data collection from Plasma Protein Therapeutics Association member companies. Transfusion 2009;49:1931-1943.

3 Horowitz B: United States: solvent/detergent plasma; in AuBuchon JP, Prowse CV (eds): Pathogen Inactivation: The Penultimate Paradigm Shift. Bethesda, AABB Press, 2010, pp 217-228.

4 Hellstern P, Sachse H, Schwinn H, Oberfrank K: Manufacture and in-vitro characterization of solvent/detergent-treated plasma. Vox Sang 1992;63: $178-185$.

$\checkmark 5$ Horowitz B, Bonomo R, Prince AM, Chin SN, Brotman B, Shulman RW: Solvent/detergent-treated plasma. A virus-inactivated substitute for fresh frozen plasma. Blood 1992;79:826-833.

6 Biesert L, Shartono H: Solvent/detergent treatment of human plasma - a very robust method for virus inactivation. Validation of virus safety of Octaplas. Vox Sang 1998;74(suppl 1):207-212.

7 Bonomo RJ: Removal of process chemicals from labile biological mixtures by hydrophobic interaction chromatography. US Patent 5.094.960. Washington, DC, US Patent Office, 1992.

$\checkmark 8$ Pelletier JPR, Transue S, Snyder EL: Pathogen inactivation techniques. Best Pract Res Clin Haematol 2006;19:205-242.

9 Woods KR, Orme TW: Removal of lipid soluble process chemicals from biological materials by extraction with naturally occurring oils or synthetic substitutes thereof. US Patent 4.789.545, Washington, DC, US Patent Office, 1988.

10 Solheim BG, Hellstern P: Pathogen inactivation of plasma and cryoprecipitate; in AuBuchon JP, Prowse CV (eds): Pathogen Inactivation: The Penultimate Paradigm Shift. Bethesda, AABB Press, 2010, pp 69-98.

11 Andreu G: France: Solvent/detergent plasma; in AuBuchon JP, Prowse CV (eds): Pathogen Inactivation: The Penultimate Paradigm Shift. Bethesda, AABB Press, 2010, pp 137-151.

12 Piquet Y, Janvier G, Selosse P, Doutremepuich C, Jouneau J, Nicolle G, Platel D, Vezon G: Virus inactivation of fresh frozen plasma by a solvent detergent procedure: biological results. Vox Sang 1992; 63:251-256.

13 Solheim BG, Cid J, Osselaer JC: Pathogen reduction technologies; in Lozano M, Contreras M, Blajchman $\mathrm{M}$ (eds): Global perspectives in transfusion medicine. Bethesda, AABB Press, 2006, pp 103-148.
14 Horowitz B, Lazo A, Grossberg H, Page G, Lippin A, Swan G. Virus inactivation by solvent/detergent treatment and the manufacture of SD-plasma. Vox Sang 1998;74(suppl 1):203-206.

15 Heger A, Svae T-E, Neisser-Svae A, Jordan S, Behizad M, Römisch J: Biochemical quality of the pharmaceutical licensed plasma OctaplasLG after implementation of a novel prion protein (PrPSc) removal technology and reduction of the solvent/detergent (S/D) process time. Vox Sang 2009;97:219-225.

16 Burnouf T, Goubran HA, Radosevich M, Sayed MA, Gorgy G, El-Ekiaby M: A process for solvent/detergent treatment of plasma for transfusion at blood centers that use a disposable bag system. Transfusion 2006;46:2100-2108.

17 El-Ekiaby M, Radosevich M, Goubran H, El Sayed M, Burnouf T. New methods of plasma fractionation - a presentation of the 'mini-pool' fractionation procedure developed in Egypt. ISBT Science Series 2009;4:99-106.

18 Horowitz B, Busch M: Estimating the pathogen safety of manufactured human plasma products: Application to fibrin sealants and to thrombin. Transfusion 2008;48:1739-1753.

19 Solheim BG, Rollag H, Svennevig JL, Arafa O, Fosse E, Bergerud U: Viral safety of solvent/detergent-treated plasma. Transfusion 2000;40:84-90.

20 Rollag H, Solheim BG, Svennevig JL: Viral safety of blood derivatives by immune neutralization. Vox Sang 1998;74(suppl 1):213-217.

21 Neisser-Svae A, Bailey A, Gregori L, Heger A, Jordan S, Behizad M, Reichl H, Römisch J, Svae TE: Prion removal effect of a specific affinity ligand introduced in the manufacturing process of the pharmaceutical quality solvent/detergent (S/D)-treated plasma OctaplasLG. Vox Sang 2009;97:226-233.

22 Svae TE, Neisser-Svae A, Bailey A, Reichl H, Biesert L, Schmidt T, Heger A, Römisch J: Prion safety of transfusion plasma and plasma-derivatives typically used for prophylactic treatment. Transfus Apher Sci 2008;39:59-67.

23 Sinnot P, Bodger S, Gupta A, Brophy M: Presence of HLA antibodies in single-donor-derived fresh frozen plasma compared with pooled, solvent detergent-treated plasma $\left(\right.$ Octaplas $\left.^{\circledR}\right)$. Eur J Immunogenet 2004;31:271-274

24 Sachs UJH, Kauschat D, Bein G: White blood cell-reactive antibodies are undetectable in solvent/ detergent plasma. Transfusion 2005;45:1628-1631.

25 Runkel S, Haubelt H, Hitzler W, Hellstern P: The quality of plasma collected by automated apheresis and of recovered plasma from leukodepleted whole blood. Transfusion 2005;45:427-432.

26 Hellstern P: Solvent/detergent-treated plasma: composition, efficacy, and safety. Curr Opin $\mathrm{He}-$ matol 2004;11:346-350.

27 Solheim BG, Hellstern P: Composition, efficacy, and safety of S/D-treated plasma. Transfusion 2003; 43:1176-1178.
28 Heiden M, Salge U, Breitner-Ruddock S, Humfeld A, Koenig H, Seitz R: Significant differences between S/D plasma qualities of different origin (abstract). Transfusion 2003; 43(suppl):56A

29 Salge-Bartels U, Breitner-Ruddock S, Hunfeld A, Seitz R, Heiden M: Are quality differences responsible for different adverse reactions reported for SD-plasma for USA and Europe? Transfus Med 2006;16:266-275.

30 Burnouf T, Goubran HA, Radosevich M, Sayed MA, Gorgy G, El-Ekiaby M: Impact of Triton X-100 on alpha2-antiplasmin (SERPINF2) activity in solvent/ detergent treated plasma. Biologicals 2007;35:349-353.

31 Murphy WG, Mikulich O: Ireland: Imported USsource solvent/detergent plasma; in AuBuchon JP, Prowse CV (eds): Pathogen Inactivation: The Penultimate Paradigm Shift. Bethesda, AABB Press, 2010, pp 153-167.

32 Solheim BG, Svennevig JL, Mohr B, Dragsund M, Noddeland H, Töllefsrud S, Brosstad F, Rollag H, Mollnes TE: The use of Octaplas in patients undergoing open heart surgery; in Müller-Berghaus G (ed): DIC: Pathogenesis, Diagnosis and Therapy of Disseminated Intravascular Fibrin Formation. Amsterdam, Elsevier, 1993, pp 253-262.

33 Heim MU, Meyer B, Hellstern P: Recommendations for the use of therapeutic plasma. Curr Vasc Pharmacol 2009;7:110-119.

34 Tølløfsrud S, Noddeland H, Svennevig JL, Bentsen G, Mollnes TE, Solheim BG: Universal fresh frozen plasma (Uniplas): a safe product on open-heart surgery. Intensive Care Med 2003;29:1736-1743.

35 Solheim BG, Granov DA, Juralv VA, Krawczyk M, Kubishkin VA, Patutko UI, Raab R: Universal fresh-frozen plasma (Uniplas): an explanatory study in adult patients undergoing elective liver resection. Vox Sang 2005;89:19-26.

36 Scully M, Longair I, Flynn M, Berryman J, Machin SJ: Cryosupernatant and solvent detergent freshfrozen plasma (Octaplas) usage in a single centre in acute thrombotic thrombocytopenic purpura. Vox Sang 2007;93:154-158.

37 Hellstern P: Fresh-frozen plasma, pathogen-reduced single-donor plasma or bio-pharmaceutical plasma? Transfus Apher Sci 2008;39:69-74.

38 Solheim BG, Flesland $\varnothing$ : Norway: solvent/detergent plasma; in AuBuchon JP, Prowse CV (eds): Pathogen Inactivation: The Penultimate Paradigm Shift. Bethesda, AABB Press, 2010, pp 125-135.

39 Krusius T, Auvinen M-K, Tuimala: Introduction of Octaplas ${ }^{\circledR}$ in clinical use decreased the rate of serious adverse reactions. Vox Sang 2010;99(suppl 1): P-1018.

40 Solheim BG, Bergan A, Brosstad F, Innes R, Svennevig JL: Fibrinolysis during liver transplant is enhanced by using solvent/detergent virus inactivated plasma (ESDEP/Ocatplas ${ }^{\circledR}$ ) (Letter) Anesth Analg 2003;96:1230-1231. 